\title{
Leishmania chagasi in dogs from the city of Jaciara, Mato Grosso, Brazil
}

\author{
Leishmania chagasi em cães no município de Jaciara, Mato Grosso, Brasil
}

\author{
Patrícia Lazari ${ }^{\mathrm{I}}$ Arleana do Bom Parto Ferreira de Almeida ${ }^{\mathrm{II}}$ Valéria Dutra ${ }^{\mathrm{II}}$ \\ Luciano Nakazato ${ }^{\text {II }}$ Álvaro Felipe de Lima Ruy Dias ${ }^{I}$ Veruska Nogueira de Brito ${ }^{\text {III }}$ \\ Cenita Maria Oliveira ${ }^{\mathrm{IV}}$ Valéria Régia Franco Sousa ${ }^{\mathrm{II}^{*}}$
}

\section{ABSTRACT}

The aim of this study was to identify the Leishmania species in Jaciara dogs; visceral leishmaniasis (VL) is endemic in the county of Jaciara. A comparison among the PCR results for the spleen, bone marrow, skin and blood of 101 dogs with VL-reactive serum were evaluated. Spleen tissue showed the highest detection percentage, followed by bone marrow. In 97 (96.04\%) dogs, the Leishmania DNA detected was confirmed as $\mathbf{L}$. chagasi, emphasizing the importance of aetiological identifications in sympatric areas with other trypanosomatids.

Key words: dog, visceral leishmaniasis, PCR, different tissues.

\section{RESUMO}

Com o objetivo de identificar a espécie de Leishmania circulante em cães de Jaciara, município endêmico para leishmaniose visceral (LV), e comparar pela PCR a detecção em baço, medula óssea, pele e sangue, foram avaliados 101 cães sororreagentes para LV. O baço foi o tecido que apresentou melhor percentual de detecção, seguido da medula óssea. Em 97 (96,04\%) cães, foi detectado DNA de Leishmania confirmada como L. chagasi, ressaltando a relevância da identificação etiológica em área de simpatria com outros tripanosomatideos.

Palavras-chave: cão, leishmaniose visceral, PCR, distintos tecidos.

Visceral leishmaniasis (VL) is a zoonotic disease that is transmitted by sand flies and caused by $\boldsymbol{L}$. chagasi (syn. L. infantum) in the Americas. The dog is considered the primary reservoir of the aetiologic agent of VL, and dogs have an important role in maintaining the disease transmission cycle in urban areas because of the parasitism of their skin, regardless of the dogs clinical presentation and proximity to man (BRASIL, 2006; BRITO et al., 2014a, b).

Various tissues, such as blood, skin, spleen, bone marrow, liver, and lymph nodes, have been identified as good sites for the parasitological confirmation of canine visceral leishmaniasis (CVL) (LACHAUD et al., 2002; ALMEIDA et al., 2013; RAMOS et al., 2013). The ease of obtaining the sample, the clinical status of the animal and the laboratory technique should be considered for the diagnosis (MARTÍNEZ et al., 2011). In accordance to this list of considerations, the Polymerase Chain Reaction has emerged as an important alternative diagnostic technique (LACHAUD et al., 2002; GOMES et al., 2007), which has adequate sensitivity to detect the DNA of the agent in host tissue prior to the occurrence of seroconversion, providing an early diagnosis of the infection (REIS et al., 2013).

In areas of sympatry with other trypanosomatid agents, the identification of circulating Leishmania species in dogs is an important component in the epidemiological study of leishmaniasis, and diagnosis by PCR has been used for this purpose (ALMEIDA et al., 2013). The municipality of Jaciara has presented VL cases since 2003 with a prevalence of $54.7 \%$ CVL (BRITO et al., 2014a; 2014b; LOPES et al., 2014) without the confirmation of Leishmania

\footnotetext{
'Programa de Pós-graduação em Ciências Veterinárias, Faculdade de Agronomia, Medicina Veterinária e Zootecnia (FAMEVZ), Universidade Federal de Mato Grosso (UFMT), Cuiabá, MT, Brasil.

IIDepartamento de Clínica Médica Veterinária, FAMEVZ, UFMT, Cuiabá, MT, Brasil. E-mail: regia@ufmt.br. "Corresponding author.

IIIVigilância Ambiental em Saúde, Secretaria Estadual de Saúde de Mato Grosso, MT, Brasil.

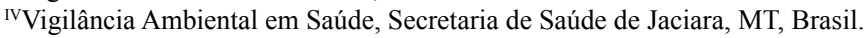


species in dogs. In this context, the aim of this study was to identify the Leishmania species in domestic dogs in the urban Jaciara area by PCR and to evaluate the use of this diagnostic technique in different tissues.

This study was conducted in the municipality of Jaciara (15 57' 22" S and 54 57' 48" $\mathrm{W})$, which is located in the Cerrado of Mato Grosso (IBGE, 2014). The dogs (which were of different breeds, ages and sexes and lived in the urban area) that were identified as seropositive by EnzymeLinked Immunosorbent Assay (ELISA) and Indirect Immunofluorescence Reaction (IFA) as part of a routine public health screening were forwarded to the Municipal Health Department for euthanasia.

The evaluated dogs were clinically classified as symptomatic, asymptomatic or oligosymptomatic (ALMEIDA et al., 2013). Blood samples were collected by venipuncture (cephalic or jugular). After the euthanasia (CFMV, 2012), bone marrow (the region of the iliac crest), skin fragments (scapular region) and spleen fragments were collected.

The sample DNA was extracted according to GOMES et al. (2007) by phenol/chloroform method. The PCR primers 150 and 152 were used for Leishmania sp. (DEGRAVE et al., 1994) and RV1 and RV2 (LACHAUD et al., 2002) were used for L. chagasi. A DNA reference strain of $\boldsymbol{L}$. infantum (MHOM / BR / 1974 / PP75) was used as positive control, and a DNA-free reaction was employed as negative control. Amplified products were fractionated by electrophoresis on a $2 \%$ agarose gel, stained with red gel and visualized by UV transillumination.

The data were analysed with Epi Info software 3.3.2 (CDC, Atlanta, USA) by chi-square or Fisher's exact tests to assess the association between the presence of Leishmania sp. DNA in different sampled tissues and the clinical status of the dogs, with a significance level of $5 \%$.

Of the 101 dogs evaluated by PCR for Leishmania sp., parasite DNA was detected in the samples from $97 \operatorname{dogs}(96.03 \%)$ and identified as
L. chagasi. In analysing the collected tissues, DNA amplification occurred in 92 (91.08\%) spleen samples, 78 (78\%) bone marrow samples, 69 (68.31\%) skin samples and 45 (44.55\%) blood samples (Table 1). In comparison with positive results between tissues, the spleen was statistically superior to Leishmania DNA detection in bone marrow $(\mathrm{P}=0.003, \mathrm{OR}=9.38$ [1.80 to 54.04]. The marrow was statistically superior to the skin for detection $(\mathrm{P}=0.004 ; \mathrm{OR}=4.49$ [1.50 to 13.70$])$. There was no significant difference among the other tissues $(\mathrm{p}>0.05)$.

In considering the clinical condition of the dogs, $1(0.99 \%)$ was rated asymptomatic, $14(13.86 \%)$ were oligosymptomatic and $86(85.14 \%)$ were symptomatic. Of these dogs, 01 (100\%), 12 (85.71\%) and $84(97.67 \%)$ were positive according to the PCR.

Several regions in Brazil are endemic for CVL, with Jaciara being one of the cities with the highest serological prevalence in Mato Grosso (BRITO et al., 2014a; LOPES et al., 2014). The observation that $96.04 \%$ of PCR positives were associated with seropositive dogs confirms the occurrence of the infection, despite of the possibility of cross-reactivity in serological tests as recommended by the Ministry of Health (BRAZIL, 2006; MADEIRA et al., 2009). This finding also enabled the identification of the $\boldsymbol{L}$. chagasi species in domestic reservoirs in Jaciara, which were previously found only in the vector (BRITO et al., 2014b).

Although there is variability in the PCR results because of the type of primers used and the target of the amplified DNA (ALMEIDA et al., 2013; REIS et al., 2013), in the present study it was used the kinetoplast DNA sequences to increase the test sensitivity by presenting a large number of parasite copies (REIS et al., 2013), which combined the use of different samples to allow a higher positivity rate.

Previous studies described an increased percentage of $\boldsymbol{L}$. chagasi DNA detection in symptomatic dogs (ALMEIDA et al., 2013), a finding that was not observed in this study. However, this discrepancy should be analysed with caution because the symptomatic dogs were numerically superior to and olygosymptomatic and

Table 1 - Leishmania chagasi detection by PCR in different tissues according to clinical status of dogs.

\begin{tabular}{lcccc}
\hline \multirow{2}{*}{ Clinical Status } & & & & \\
& Spleen $(\mathrm{n}=101)$ & Bone Marrow $(\mathrm{n}=100)$ & Skin $(\mathrm{n}=101)$ & Blood $(\mathrm{n}=101)$ \\
\hline Asymtomatic $(\mathrm{n}=01)$ & 01 & 01 & 01 & 00 \\
Oligosymptomatic $(\mathrm{n}=14)$ & 12 & 11 & 08 & $01 / 01(100)$ \\
Symtomatic $(\mathrm{n}=86)$ & 79 & 66 & 60 & $12 / 14(85,7)$ \\
TOTAL $(\%)$ & $92(91,1)$ & $78(78)$ & $69(68,3)$ & 41 \\
\hline
\end{tabular}

+- total number of positive dogs, n- sampling. 
asymptomatic, preventing a reliable statistical analysis. In this study, skin, bone marrow, blood and spleen in agreement with previous studies (MADEIRA et al., 2009; ALMEIDA et al., 2013), and the spleen showed a higher percentage of $\boldsymbol{L}$. chagasi DNA detection than the bone marrow. According to REIS et al. (2013), the spleen is considered one of the major organs affected by Leishmania sp.; however, its invasive collection hampers its applicable at a large scale. The superiority of detecting the infection in bone marrow compared with skin differs from that described by ALMEIDA et al. (2013). However, the positive difference between the sampled tissues may be related to Leishmania's tropism for lymphoid organs (RAMOS et al., 2013).

In summary, the spleen presented the strongest detection of Leishmania confirmed as Leishmania chagasi, followed by bone marrow tissue, emphasizing the importance of aetiological identification in areas with sympatric species.

\section{ACKNOWLEDGEMENTS}

This study was supported by the following grant: Universal 2011-Conselho Nacional de Desenvolvimento Científico e Tecnológico (CNPq) and Coordenação de Aperfeiçoamento de Pessoal de Nível Superior (CAPES) (AUXPE nº 3531/2014).

\section{BIOETHICS AND BIOSSECURITY COMMITTEE APPROVAL}

The consent of the dog owners was obtained and indicated by signatures on the science terms/euthanasia agreement, and the procedures were approved by the Ethics Committee on Animal Use at the Universidade Federal de Mato Grosso (CEUA/ UFMT) under protocol number 23108.018081/12-0.

\section{REFERENCES}

ALMEIDA, A.B.P.F. et al. Canine visceral leishmaniasis: diagnostic approaches based on polymerase chain reaction employing different biological samples. Diagnostic Microbiology and Infectious Disease, v.76, p.321-324, 2013. Available from: <http:// dx.doi.org/10.1016/j.diagmicrobio.2013.03.017>. Accessed: Dec. 20, 2013. doi: 10.1016/j.diagmicrobio.2013.03.017.

BRASIL. Ministério da Saúde. Departamento de Vigilância Epidemiológica. Secretaria de Vigilância em Saúde. Manual de vigilância e controle da leishmaniose visceral. Secretaria de Vigilância em Saúde. Brasília: Ministério da Saúde, 2006. 120p. Available from: <http://portal.saude.gov.br/portal/arquivos/pdf/ manual_leish_visceral2006.pdf $>$. Accessed: Dec. 20, 2013.

BRITO, V.N. et al. Epidemiological aspects leishmaniasis in Jaciara, Mato Grosso, Brazil, 2003 to 2012. Revista Brasileira de Parasitologia Veterinária, v.23, n.1, p.63-68, 2014a. Available from: <http://dx.doi.org/10.1590/S1984-29612014008>. Accessed: Sept. 17, 2014. doi: 10.1590/S1984-29612014008.
BRITO, V.N. et al. Phlebotomine fauna, natural infection rate and feeding habits of Lutzomyia cruzi in Jaciara, state of Mato Grosso, Brazil. Memórias do Instituto Oswaldo Cruz, v.109, n.7, p.899-904, 2014b. Available from: <http://dx.doi.org/10.1590/0074-0276140112>. Accessed: Nov. 05, 2014. doi: 10.1590/0074-0276140112.

CFMV (CONSELHO FEDERAL DE MEDICINA VETERINÁRIA). Resolução n.1000. Dispõe sobre os procedimentos e métodos de eutanásia e dá outras providências, 2012. 9p. Available from: <http://portal.cfmv.gov.br/portal/lei/ index/id/326>. Accessed: May 20, 2012.

DEGRAVE, W. et al. Use of molecular probes and PCR for detection and typing of Leishmania: a mini review. Memórias do Instituto Oswaldo Cruz, v.89, n.3, p.463-469, 1994. Available from: <http:// dx.doi.org/10.1590/S0074-02761994000300032>. Accessed: Mar. 27, 2014. doi: 10.1590/S0074-02761994000300032.

GOMES, A.H.S. et al. PCR identification of Leishmania in diagnosis and control of canine leishmaniasis. Veterinary Parasitology, v.144, p.234-241, 2007. Available from: <http:// dx.doi.org/10.1016/j.vetpar.2006.10.008>. Accessed: May 10, 2013. doi: 10.1016/j.vetpar.2006.10.008.

IBGE.gov.br [página da internet]. Instituto Brasileiro de Geografia e Estatística, Cidades [Citado em 25 mar 2014]. Available from: $<$ http://www.ibge.gov.br/cidadesat/topwindow.htm?1>. Accessed: Feb. 10, 2014.

LACHAUD, L. et al. Comparison of six PCR methods using peripheral blood for detection on canine visceral leishmaniasis. Journal of Clinical Microbiology, v.40, p.210-215, 2002. Available from: <http://dx.doi.org/10.1128/JCM.40.1.210-215.2002>. Accessed: May 02, 2013. doi: 10.1128/JCM.40.1.210-215.2002.

LOPES, P.M. et al. Seroprevalence and risk factors associated with visceral leishmaniasis in dogs in Jaciara, State of Mato Grosso. Revista da Sociedade Brasileira de Medicina Tropical, v.47, n.6, p.791-795, 2014. Available from: <http://dx.doi.org/10.1590/0037-8682-0027214>. Accessed: Jan. 20, 2015. doi: 10.1590/0037-8682-0027-214.

MADEIRA, M.F. et al. Parasitological diagnosis of canine visceral leishmaniasis: is intact skin a good target? Research in Veterinary Science, v.87, p.260-262, 2009. Available from: $<$ http://dx.doi. org/10.1016/j.rvsc.2009.03.008>. Accessed: Jan. 10, 2015. doi: 10.1016/j.rvsc.2009.03.008.

MARTÍNEZ, V. et al. Canine leishmaniasis: the key points for qPCR result interpretation. Parasites \& Vectors, v.4, p.57, 2011. Available from: <http://dx.doi.org/10.1186/1756-3305-4-57>. Accessed: Jan. 10, 2015. doi: 10.1186/1756-3305-4-57.

RAMOS, R.A.N. et al. Quantification of Leishmania infantum DNA in the bone marrow, lymph node and spleen of dogs. Revista Brasileira de Parasitologia Veterinária, v.22, n.03, p.346350, 2013. Available from: <http://dx.doi.org/10.1590/S198429612013000300005>. Accessed: Jan. 30, 2015. doi: 10.1590/ S1984-29612013000300005.

REIS, L. E. S, et al. Molecular diagnosis of canine visceral leishmaniasis: A comparative study of three methods using skin and spleen from dogs with natural Leishmania infantum infection. Veterinary Parasitology, v.197, n.3-4, p.498-503, 2013. Available from: $<$ http://www.ncbi.nlm.nih.gov/pubmed/23953760>. Accessed: Mar. 18, 2015. doi: 10.1016/j.vetpar.2013.07.006. 